\title{
Introductory Note
}

Charles S. Peirce was one of the most creative and innovative philosophers of the late $19^{\text {th }}$ and early $20^{\text {th }}$ century. He is known as the founder of American pragmatism, a general philosophical view which he in his later years preferred to call "pragmaticism" to distinguish it from the doctrines propounded by his followers and imitators who, according to Peirce, had "kidnapped" the word 'pragmatism'. He had wide interests, and his pragmaticism permeated his work in many areas of philosophy: logic, semiotics and the philosophy of language, philosophy of science, and metaphysics.

In the 1880s Peirce developed independently of Gottlob Frege a system of quantification theory in which quantifiers were treated as variable binding operators; thus he can be regarded, alongside Frege, as a founder of contemporary formal logic. The standard notation used in contemporary logic is a variant of Peirce's notation rather than that adopted by Frege. As a part of his pragmatic theory of meaning, Peirce developed a game-theoretical interpretation of logical constants, according to which their meaning is explained by means of a semantical zero-sum game between two parties, an utterer and an interpreter. Peirce also studied modal and many-valued logics, and developed the basic ideas of the possible-worlds semantics for modal logic. In his general theory of reasoning Peirce distinguished three main forms of reasoning, namely abduction, deduction, and induction, and revised the traditional account of non-deductive reasoning. In his work in general semiotics (the theory of signs) and the philosophy of language, he analyzed the sign relation as a triadic relation involving a sign, an interpretant (meaning), and an object, and introduced the distinction between types and tokens into linguistics and the philosophy of language. He made a distinction between iconic, indexical, and symbolic signs, and outlined an account of proper names as "directly referential" indexical signs. Peirce developed a complex classification of signs involving several interpretants and objects, and his rich semiotic system provides a useful framework for the comparison of semiotic theories from the Stoics to the present. He anticipated many significant developments in the later $20^{\text {th }}$ century analytic philosophy and logic.

In the 1890s Peirce reformulated quantification theory by expressing it in a language of diagrams which he called existential graphs. The switch from the algebraic notation to the language of graphs seems to have been motivated by his belief that the latter was more suitable for the purposes of logical analysis. According to Peirce, a system of logic can be used as a calculus which helps to draw inferences as economically as possible, or it can be developed for the purpose of representing and analyzing deductive processes. Peirce also thought that a graph- 
ical notation was more suitable for logical analysis than an algebraic notation because of its higher degree of iconicity. An iconic sign can be said to show what it means in the sense that it resembles its objects in some respect, that is, some features of the sign itself determine its interpretation. Peirce himself regarded the theory of existential graphs as one of his most important contributions to logic and philosophy.

Peirce presented his theory of existential graphs in many papers which also discussed various philosophical topics in semiotics and the philosophy of language. Much of this material remained unpublished during his lifetime, and some scholars became acquainted with it by studying his manuscripts. On the other hand, Peirce was able to get some of these works published, for example, his work A Syllabus of Certain Topics of Logic was published by Alfred Mudge \& Son, Boston, 1903, and the long paper "Prolegomena to an Apology for Pragmaticism" appeared in the philosophical journal The Monist in 1906. However, Peirce's contemporaries ignored these works, perhaps because they were not able to see them as significant contributions to logic and philosophy. It might be said that Peirce was ahead of his times; his work on existential graphs began to receive serious attention only in the 1960s.

The three books of the Logic of the Future series are the first comprehensive collection of Peirce's writings on existential graphs, especially his previously unpublished writings and unpublished variants of published works. Peirce had the habit of rewriting the same work several times, and the versions often differ from each other in interesting ways. Prof. Ahti-Veikko Pietarinen has performed a valuable service to all students of Peirce's logic and philosophy by making this material easily accessible in book form.

Risto Hilpinen

University of Miami, Coral Gables 